Volume 7 Nomor 3 Tahun 2019

\title{
The Application of Cooperative Script Type Model to Improve Intensive Reading Skills in Grade III Students of SD Negeri 1 Panjer in Academic Year 2018/2019
}

\author{
1,2,3Universitas Sebelas Maret \\ chalisanurul19@gmail.com
}

Chalisa Nurul IImi ${ }^{1}$, Suhartono ${ }^{2}$, Rokhmaniyah ${ }^{3}$

\section{Article History}

accepted 01/10/2019

approved 01/11/2019

published 01/12/2019

\begin{abstract}
This study aimed to describe the application of the Cooperative Script model, to improve intensive reading skills, and to improve intensive reading skills through the application of Cooperative Script. This classroom action research (CAR) was carried out for three cycles. The subjects of this study were third grade students of SD N 1 Panjer in Academic Year 2018/2019, totalling 23 students. Data collection techniques used were observation, interviews, and tests. Data validity used technique triangulation and sources Analysis of quantitative was analyzed with comparative descriptive statistical techniques and qualitative included data reduction, data presentation, and conclusion. The results of the study indicated that the application of the Cooperative Script model could improve intensive reading skills in grade III students of SD Negeri 1 Panjer in Academic Year 2018/2019.
\end{abstract}

Keywords: cooperative script, intensive reading skills

\section{Abstrak}

Tujuan penelitian ini yaitu mendeskripsikan penerapan model kooperatif tipe Cooperative Script, untuk meningkatkan keterampilan membaca intensif dan meningkatkan keterampilan membaca intensif melalui penerapan model kooperatif tipe Cooperative Script. Penelitian ini adalah penelitian tindakan kelas kolaboratif (PTK) yang dilaksanakan dalam tiga siklus. Subjek penelitian ini adalah siswa kelas III SD N 1 Panjer tahun ajaran 2018/2019 yang berjumlah 23 siswa. Teknik pengumpulan data menggunakan observasi, wawancara, dan tes. Validitas data menggunakan teknik triangulasi dan sumber. Analisis data kuantitatif dianalisis dengan teknik statistik deskriptif komparatif dan kualitatif meliputi reduksi data, penyajian data, dan kesimpulan. Hasil penelitian ini menunjukkan bahwa penerapan model kooperatif tipe Cooperative Script dapat meningkatkan keterampilan membaca intensif siswa kelas III SD Negeri 1 Panjer tahun ajaran 2018/2019.

Kata Kunci: cooperative script, keterampilan membaca intensif 


\section{PENDAHULUAN}

Bahasa adalah suatu hal yang sangat penting bagi seseorang untuk berkomunikasi dan berinteraksi dengan orang lain. Sumantri \& Syaodih (2008: 2.30) mengemukakan bahwa bahasa adalah bentuk komunikasi di mana pikiran dan perasaan seseorang disimbolkan agar dapat menyampaikan arti kepada orang lain. Melalui bahasa, seseorang dapat menyampaikan pesan, perasaan, gagasan, pikiran, dan pengalamannya kepada orang lain dengan mudah.

Tarigan (2015: 1) menyebutkan bahwa ada empat keterampilan berbahasa yang harus dimiliki setiap siswa sebagai hasil belajar. Keempat jenis keterampilan tersebut yakni keterampilan menyimak (listening skills), keterampilan berbicara (speaking skills), keterampilan membaca (reading skills), dan keterampilan menulis (writing skills). Keterampilan membaca merupakan suatu keterampilan berbahasa yang memiliki peranan penting untuk mengakses informasi dan pengetahuan dari penjuru dunia.

Keterampilan membaca pada dasarnya menjadi suatu kebutuhan yang harus dipenuhi sehingga keterampilan membaca harus dilatih sejak dini. Sekolah Dasar menjadi lembaga pendidikan pertama yang melatih siswa untuk menguasai keterampilan membaca yang terdapat pada mata pelajaran bahasa Indonesia. Burns, dkk (Rahim, 2009: 1) mengemukakan "Kemampuan membaca merupakan sesuatu yang vital dalam suatu masyarakat terpelajar."

Menurut Purwanti (2016: 44) keterampilan membaca bagi siswa yang duduk di Sekolah Dasar menjadi sebuah jembatan untuk memahami ilmu-ilmu lain. Jika ia tidak memiliki kemampuan itu, maka ia akan senantiasa tertinggal dan tidak memiliki informasi lainnya yang seharusnya mereka ketahui. Akibat jika siswa belum mampu membaca dengan penuh pemahaman maka membuat siswa tidak mampu menguasai banyak mata pelajaran lainnya. Salah satu bentuk keterampilan membaca yaitu keterampilan membaca intensif.

Keterampilan membaca intensif tidak semata-mata melekat pada diri seseorang, melainkan perlu latihan dan diasah secara berulang-ulang. Hal ini menunjukkan bahwa seorang pendidik dituntut mampu menyajikan pembelajaran dengan baik dan tepat dalam menyampaikan materi keterampilan menulis seperti keterampilan membaca intensif. Selain itu, pendidik juga harus komunikatif dalam melakukan pembelajaran dengan penggunaaan bahasa yang mudah dimengerti oleh siswa. Dengan demikian, tujuan pembelajaran yang diharapkan dapat tercapai dan pembelajaran tidak membosankan.

Berdasarkan observasi yang dilaksanakan di SD Negeri 1 Panjer pada hari Selasa tanggal 13 November 2018,, peneliti menemukan bahwa proses pembelajaran bahasa Indonesia di kelas III SD Negeri 1 Panjer: (1) siswa pasif dalam pembelajaran, kurangnya antusias siswa dalam proses pembelajaran; (2) Siswa mudah bosan menyebabkan siswa berisik atau ramai di dalam kelas; (3 proses pembelajaran yang dikemas guru masih menggunakan model ekspositori (teacher centered) dan belum menggunakan model pembelajaran yang melibatkan siswa untuk aktif; (4) nilai keterampilan membaca intensif siswa termasuk rendah karena siswa yang mencapai $\mathrm{KKM}(\mathrm{KKM}=75)$ sebanyak 12 anak atau $52 \%$ dari jumlah siswa kelas III sejumlah 23 siswa. Hal tersebut di atas disebabkan karena kurangnya penerapan model pembelajaran yang dapat menarik perhatian siswa dalam pembelajaran bahasa.

Salah satu upaya untuk meningkatkan pembelajaran bahasa Indonesia, khususnya keterampilan membaca intensif, dengan menerapkan model pembelajaran. Peneliti beranggapan bahwa penerapan model pembelajaran kooperatif tipe Cooperative Script merupakan model yang cocok untuk meningkatkan keterampilan membaca intensif siswa kelas III di SD Negeri 1 Panjer, sebab siswa dilatih untuk mengembangkan jiwa keberanian dalam menyampaikan ide atau gagasan. Susiloyoga (2016: 40) model pembelajaran Cooperative Script baik digunakan dalam 
pembelajaran untuk menumbuhkan ide-ide atau gagasan baru (dalam pemecahan suatu permasalahan), daya berfikir kritis serta mengembangkan jiwa keberanian dalam menyampaikan hal-hal baru yang diyakininya benar. Menurut Huda (2013: 214) kelebihan model pembelajaran Cooperative Script antara lain memudahkan siswa berdiskusi dan melakukan interaksi sosial; memotivasi siswa yang kurang pandai agar mampu mengungkapkan pemikirannya; dan meningkat kemampuan berpikir kreatif siswa.

Berdasarkan uraian di atas, dapat dirumuskan masalah sebagai berikut: (1) bagaimana penerapan model kooperatif tipe Cooperative Script untuk meningkatkan keterampilan membaca intensif; (2) apakah penerapan model kooperatif tipe Coopertive Script dapat meningkatkan keterampilan membaca intensif.

Tujuan penelitian ini, yaitu (1) mendeskripsikan penerapan penerapan model kooperatif tipe Cooperative Script untuk meningkatkan keterampilan membaca intensif; (2) meningkatkan keterampilan membaca intensif melalui penerapan model kooperatif Cooperative Script.

\section{METODE}

Penelitian ini dilaksanakan di SD Negeri 1 Panjer yang berlangsung dari bulan November 2018 sampai Februari 2019. Subjek penelitian ini adalah siswa kelas III yang berjumlah 23 siswa yang terdiri dari 12 siswa laki-laki dan 11 siswa perempuan.

Data pada penelitian ini ada dua macam yaitu data mengenai penerapan model Cooperative Script dan data mengenai hasil keterampilan membaca intensif siswa. Adapun teknik pengumpulan data yang digunakan adalah observasi, wawancara, dan tes.

Teknik uji validitas data pada penelitian ini menggunakan teknik triangulasi yaitu triangulasi teknik dan sumber. Triangaulasi teknik yang digunakan yaitu observasi, wawancara, dan tes. Adapun triangulasi sumber yang digunakan yaitu siswa dan guru. Teknik analisis data kuantitatif dianalisis dengan teknik statistik deskriptif komparatif dan kualitatif meliputi reduksi data, penyajian data, dan kesimpulan sesuai model analisis data menurut Miles dan Huberman (Sugiyono, 2017: 247)

Indikator kinerja penelitian ini adalah penerapan model Cooperative Script dan peningkatan keterampilan membaca intensif $(K K M=75)$ ditargetkan mencapai 85\%. Adapun prosedur penelitian ini menggunakan model penelitian tindakan kelas yang terdiri dari empat tahapan, yaitu (1) perencanaan, (2) pelaksanaan, (3) observasi, (4) refleksi.

\section{HASIL DAN PEMBAHASAN}

Penerapan model kooperatif tipe Cooperative Script untuk meningkatkan keterampilan membaca intensif siswa kelas III SD Negeri 1 Panjer dilakukan dalam tiga siklus. Setiap siklus terdiri dari dua pertemuan, dengan alokasi waktu 2x35 menit setiap pertemuan.

Proses pembelajaran dilaksanakan dengan langkah-langkah sebagai berikut: (1) membagi kelompok secara berpasangan; (2) membagi bahan bacaan; (3) menetapkan peran; (4) melaksanakan membaca intensif; (5) menyampaikan hasil diskusi (6) bertukar peran; dan (7) menyimpulkan. Langkah-langkah pembelajaran model kooperatif tipe Cooperative Script tersebut mengacu pada langkah-langkah yang dikemukakan oleh Warsono dan Hariyanto (2012: 205) dan Huda (2013: 214) yang kemudian disimpulkan menjadi langkah yang sudah disebutkan di atas.

Hasil observasi penerapan model kooperatif tipe Cooperative Script mengalami peningkatan pada setiap siklusnya hingga mencapai kinerja penelitian yang ditargetkan sebesar $85 \%$. 


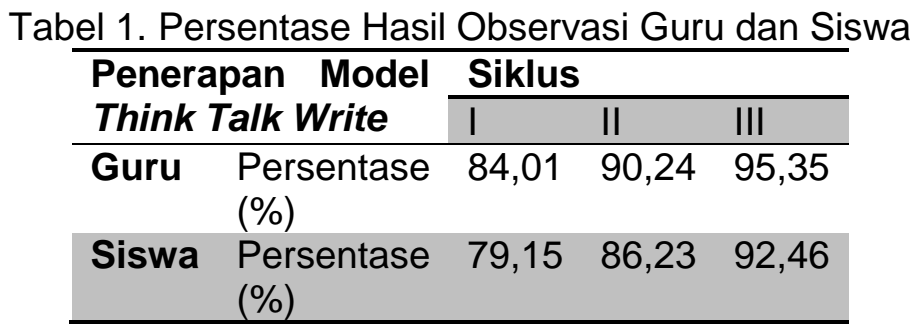

Berdasarkan Tabel 1, persentase rata-rata hasil observasi guru pada siklus I yaitu $84,01 \%$. Siklus II meningkat menjadi $90,24 \%$ dan siklus III menjadi $95,35 \%$. Hasil observasi siswa pada siklus I dengan persentase $79,15 \%$, mengalami peningkatan pada siklus II menjadi $86,23 \%$ dan siklus III menjadi $92,46 \%$.

Tabel 2. Keterampilan Membaca Intensif Siswa Siklus I, II, dan III

\begin{tabular}{llll}
\hline & Siklus & Siklus & $\begin{array}{l}\text { Siklus } \\
\text { IIII }\end{array}$ \\
\hline Tuntas & 65,21 & 76,09 & 86,96 \\
Belum & 34,79 & 23,91 & 13,04 \\
Tuntas & & & \\
\hline
\end{tabular}

Berdasarkan tabel di atas, dapat disimpulkan bahwa ketuntasan keterampilan menulis puisi siswa mengalami peningkatan. Pada siklus I persentase ketuntasan siswa yaitu $65,21 \%$. siklus II persentase ketuntasan yaitu 76,09\%. Sedangkan pada siklus III meningkat menjadi $86,96 \%$. Berdasarkan hasil observasi dan wawancara, guru berhasil menerapkan langkah langkah model kooperatif tipe Cooperative Script dan siswa dapat mengikuti pembelajaran dengan baik.

Dengan demikian penerapan model kooperatif tipe Cooperative Script dapat meningkatkan keterampilan membaca intensif siswa yang dilihat dari persentase siswa yang memenuhi ketercapaian target dari siklus I-III. Hasil penelitian ini memperkuat penelitian yang dilakukan Sulasih (2015) yang menyatakan bahwa membuktikan bahwa penerapan Cooperative Script dapat meningkatkan keterampilan membaca intensif dalam pembelajaran.

\section{SIMPULAN}

Penerapan model kooperatif tipe Cooperative Script untuk meningkatkan keterampilan membaca intensif siswa kelas III SD Negeri 1 Panjer tahun ajaran 2018/2019 dilaksanakan dengan langkah-langkah: (1) membagi kelompok secara berpasangan; (2) membagi bahan bacaan; (3) menetapkan peran; (4) melaksanakan membaca intensif; (5) menyampaikan hasil diskusi (6) bertukar peran; dan (7) menyimpulkan

Penerapan model kooperatif tipe Cooperative Script dapat meningkatkan keterampilan membaca intensif siswa kelas III SD Negeri 1 Panjer tahun ajaran 2018/2019, ditunjukkan dengan peningkatan persentase siswa pada setiap siklus yang memenuhi ketercapaian target indikator penelitian sebesar $85 \%$.

\section{DAFTAR PUSTAKA}

Huda, M. (2013). Model-model Pengajaran dan Pembelajaran. Yogyakarta: Pustaka Pelajar.Dalman. (2016). Keterampilan Menulis. Jakarta: PT. Raja Grafindo Persada.

Purwanti. (2016). Peningkatan Kompetensi dan Hasil Belajar Bahasa Indonesia Materi Teks Percakapan Melalui Metode PQRST Siswa Kelas VI SDN Ngastorejo. Jurnal IImiah "Pendidikan Dasar", 3 (1), 43-52. Diperoleh pada 18 Januari 
2019, dari https://media.neliti.com/media/publications/96662-ID-peningkatankompetensi-dan-hasil-belajar.pdf

Rahim, F. (2009). Pengajaran Membaca di Sekolah Dasar Edisi Kedua Cetakan Keempat. Jakarta: PT Bumi Aksara.

Sugiyono. (2017). Metode Penelitian Pendidikan Pendekatan Kuantitatif, Kualitatif, dan $R \& D$. Bandung: Alfabeta.

Sulasih. (2015). Penggunaan Model Cooperative Script dengan Bahan Bacaan Koran untuk Meningkatkan Keterampilan Membaca Intensif di Kelas IV SDN Peneket Tahun Ajaran 2014/2015. Skripsi Tidak Diplublikasikan. Universitas Sebelas Maret, Surakarta.

Sumantri, M. \& Syaodih, N. (2008). Perkembangan Peserta didik. Jakarta: Unversitas Terbuka.

Suprijono, A. (2013). Cooperative Learning Teori dan Aplikasi Paikem. Yogyakarta: Pustaka Pelajar.

Susiloyoga, J. (2016). Upaya Meningkatkan Kemampuan Menentukan Peluang Suatu Kejadian dengan Model Pembelajaran Kooperative Script pada Siswa Kelas IX-IPA 3 SMA Negeri 2 Madiun. Jurnal IImiah Edukasi Matematika, 39-62. Diperoleh pada 5 Januari 2019, dari http://portal.widyamandala.ac.id/jurnal/index.php/jiem/article/view/365

Tarigan, H.G. (2015). Membaca Sebagai Suatu Ketrampilan Berbahasa. Bandung: CV Angkasa.

Warsono dan Hariyanto. (2012). Pembelajaran Aktif: Teori dan Asesmen. Bandung: Rosda. 